$10.21867 / \mathrm{KjK} / 2016.2 .5$.

\title{
AZ IGAZOLÁS KULTÚRÁJA ÉS A KÖZJÓ - MEgJEGYZÉSEK AZ ALKOTMÁNYBÍRÓSÁG TULAJDONJOG-KORLÁTOZÁSI GYAKORLATÁHOZ
}

\section{Sólyom Péter ${ }^{1}$}

I. Arra, hogyan tudja egy kormányzat a saját szolgálatába állítani az alkotmánybíróságot, megvannak az ismert minták. Ebben az írásban nem is ezzel akarok foglalkozni, inkább egy másik irányból közelítenék a kérdéshez: az igazolás kultúrájának a jelentőségére szeretném felhívni a figyelmet.

Annak a nézőpontnak, amit az igazolás kultúrájának nevezek, a középpontjában a társadalmi konfliktusok és a politikai verseny logikája által kitermelt politikai NEM áll, egy olyan a többség által meghozott közösségi vagy a közösség nevében meghozott döntés, amellyel a közösség másik, kisebbségben maradt része nem ért egyet. Vagy azért, mert sérti az érdekeit, vagy azért, mert a világnézete miatt nem fogadható el. Az egyet nem értés jelentősége abban áll, hogy rávilágítson arra, hogy a demokratikus jogállamban a kormányzás a politikai közösség egészének a nevében és felhatalmazásából történik. Ebben az értelemben az állam demokratikus szervezeti elve arról szól, hogy segítsen érvényre juttatni a közösség minden tagjának önmeghatározáshoz való jogát. Azoknak a tagoknak is, akik a döntéshozatal során kisebbségben maradtak. A demokrácia elv alkalmazási területe ebben az összefüggésben azokra közhatalmat gyakorló intézményekre korlátozódik, amelyek az egyén önmeghatározáshoz való jogát érvényre juttatják.

Klasszikus kérdés: milyen méltányos megoldásai lehetnek az egyet nem értések feloldásának. Az egyenlőség elve és a közösségi döntések hatékonyságának a szempontjai alapján a többségi döntéshozatal mellett szólnak a legerösebbek érvek. A többségi döntéshozatal kizárólagossága azonban súlyos igazolási kérdéseket vet fel a kisebbség szempontjából. Milyen körülmények között szólnak jó érvek amellett, hogy a politikai kisebbséghez tartozóként továbbra is a politikai közösség egyenlően kezelt tagjának tekinthetem magam? Mikor szólnak ésszerü érvek a közösség elhagyása mellett? Ronald Dworkin sokat idézett válasza ${ }^{2}$ szerint ,akkor gondolhatjuk értelmesen egy csoportról, hogy önmagát kormányozza, (...) ha a politikai döntések tétje mindenki számára egyenlő (...): mindenkinek a sorsa pont ugyanannyit kell számítson, mint bárki másé, aki a döntésben érintett."

De hogyan lehet ellenörizni azt, hogy a többség által hozott döntések minden fontos érdeket egyenlően mérlegeltek? Akkor, ha a közösségi döntéshozatal intézményesítése során lehetőséget biztosítunk a döntéseket igazoló érvek alapos mérlegelésére, és lehetőség van az igazolhatatlan döntések korrekciójára.

II. A magyar alkotmánybíróság elmúlt bő húsz évét nem kevés politikai vita kísérte. De egy bizonyos: meghonosította a magyar jogi kultúrában a részletes érvekkel kifejtett igazolás beszédmódját. Ez pedig egy sokszor alulbecsült nagyon értékes teljesítmény. Még akkor is, ha a jelenlegi testület már igyekszik elfelejteni ezt a nyelvet, és nemrég elhagyta a testületet az utolsó olyan bíró is, aki a különvéleményeiben ápolta az igazolás kultúráját. Ebben az írásban arra szeretném felhívni a figyelmet, hogy milyen veszteség éri a magyar alkotmányos kultúrát, ha már nem lesz olyan bíró a testületben, aki ezt a nyelvet értően és érthetően beszéli.

\footnotetext{
${ }^{1}$ Sólyom Péter, mb. tanszékvezető egyetemi docens, DE ÁJK

${ }^{2} \mathrm{http}$ ://szuveren.hu/vendeglap/ronald-dworkin/mi-a-demokracia
} 
Az igazolás kultúrájának a középpontjában az alapjogok korlátozásának elfogadható indokai állnak. Egy alapjog korlátozása akkor elfogadható, ha a korlátozás szükségessége mellett meggyőző, legitim indokokat tudnak felhozni. ${ }^{3}$ Önmagában az az indok, hogy a törvény egyébként legitim célját csak valamelyik alapjog korlátozásával lehet elérni, még nem igazolja az alapjog-korlátozást. Nem mindegy ugyanis, hogy a törvény milyen mértékben korlátozza az alapvető jogot. A korlátozás mértéke csak akkor elfogadható, ha igazolható, hogy a törvény által választott szabályozási megoldás a kitüzött célok elérése érdekében a lehető legkisebb mértékben korlátozza az alapvető jogokat. Tehát nincs másik olyan szabályozási alternatíva, amely ugyanazt a célt kevesebb jogkorlátozással tudná megoldani. Az alapjog-korlátozás mértékének az igazolását nevezzük arányossági vizsgálatnak.

Az arányossági vizsgálatok meggyőző ereje fejezi ki az adott intézmények igazolási kultúrájának teljesítményét. Az olyan intézményes rendszerek, amelyekben nincsenek általános elfogadott módszerek arra, hogyan végezzék el ezeket az arányossági vizsgálatokat, rövid úton komoly legitimációs deficiteket felhalmozó, az alapvető jogokat önkényesen korlátozó gyakorlatokká válnak. Az elmúlt évek tulajdonjoggal összefüggő döntései egyrészt világosan jelzik az arányossági vizsgálatok jelentőségét, másrészt pedig jól mutatják, milyen súlyos válságban van az igazolás kultúrája ma Magyarországon.

A tulajdonjogi ügyek sajátossága, hogy a tulajdonjog alapjog-korlátozási tesztje eltérő a többi alapvető jogétól, mert ebben az esetben a közérdek is legitim korlátozási indoknak számít, de a szükségesség és az arányosság igazolásának az igényében ez a jog is osztozik a többi alapvető joggal. Mivel a döntéseket részletesen elemezték már az alkotmányjogi diskurzusban, ${ }^{4}$ csak az érvelések legnyilvánvalóbb hiányosságaira utalok.

III. Az első ügy ${ }^{5}$ alapja a Szerencsejátékokról szóló törvény 26. § (3) bekezdése, amelynek első mondata alapján 2012. október 10-ét követően pénznyerő automata kizárólag játékkaszinóban, egy gazdasági társaság által üzemeltethető. A módosított törvény 40/A. § (1) bekezdése kifejezetten rendelkezik arról, hogy a törvénymódosítás hatálybalépését megelőzően kiállított, pénznyerő automata üzemeltetésére jogosító engedélyek a törvénymódosítás hatálybalépését követő napon hatályukat vesztik. A törvény azonnali hatállyal vált alkalmazhatóvá.

A törvénymódosítások korlátozták a tulajdonhoz való jogot, mert arra kötelezték a vállalkozókat, hogy a müködő, engedéllyel rendelkező gépeiket vonják ki a forgalomból, vagyis a hasznot, munkát teremtő tevékenységük alapját képező vagyon értéktelenné, sőt kötelezően megsemmisítendő tulajdontárggyá vált. A tulajdonjog korlátozását súlyosbította, hogy a vállalkozóknak nem volt idejük felkészülni az új szabályozásra. A jogszabály megjelenését követően 7 óra állt a vállalkozó rendelkezésére a pénznyerő automaták elszállítására.

Az Alkotmánybíróság úgy vélte, hogy a jogalkotó azon törekvése, hogy szociális, egészségügyi és gazdasági okokból radikálisan csökkentse a társadalom leginkább veszélyeztetett csoportjai, rétegei hozzáférhetőségét a pénznyerő automatákhoz, közérdekünek tekinthető. A szerencsejátékok formái közül a pénznyerő automaták ugyanis kiemelt, szignifikáns szerepet játszanak a játékszenvedély és az ahhoz vezető játékfüggőség okozásában.

\footnotetext{
${ }^{3}$ Például más alapjogának a védelme, vagy valamilyen alkotmányos érdek.

${ }^{4} \mathrm{https}: / /$ jema.hu/article.php?c=289

${ }^{5} \mathrm{http}: / /$ public.mkab.hu/dev/dontesek.nsf/0/DBD7732C2737B486C1257AF70020F8C0?OpenDocument
} 
„Az Alkotmánybíróság szerint a Módtv. hatályba léptetése valóban nem biztosított felkészülési időt, azt viszont a nemzetbiztonsági kockázat elleni minél sürgősebb fellépés tette szükségessé. Ebben az esetben a felkészülési idő biztosítása a hatályba léptetett jogszabály végrehajtásának hatékonyságát redukálva éppen a jogalkotói szándék ellen hatott volna."

Az Alkotmánybíróság megállapította, hogy a pénznyerő automatákra vonatkozó állami monopólium létrehozásához, a játéklehetőségek szük keretek közé korlátozásához nyomós közérdek füződik, amelyet szociális, egészségügyi és gazdasági okok igazolnak, mint például a játékszenvedély elfogadható szintre való redukálása és a kísérő összetett negatív hatásainak - beleértve a bünözést, pl. a pénzmosást és a sikkasztást - az eröteljes csökkentése.

A bíróság az ítéletében hangsúlyozta, hogy a jogalkotó széleskörü mérlegelési lehetőségekkel rendelkezik annak meghatározására, hogy milyen veszélyektől kell megóvni a társadalmat, és az indítványozók által támadott jogalkotói beavatkozás könnyebb és közvetlenebb ellenörzést tesz lehetővé az állam számára a jogalkotó által kitüzött célok elérése érdekében. Majd pedig jön a számunkra legfontosabb fordulat a döntésben: „A fenti megállapitások igazolják a jogalkotói beavatkozás arányosságát”.

A bíróság állítása azért meglepő, mert az érvelés alapján az arányossági vizsgálat el sem kezdődött, a bíróság érvelése csupán az alapjog korlátozás szükségességét ismerte el, és a közérdekre hivatkozást legitim célként fogadta el. Ha újraolvassuk, akkor talán a nemzetbiztonsági kockázatra hivatkozásnak van kihatása az arányossági vizsgálatra. Ami azért különösen érdekes, mert a bíróság úgy fogadta el a nemzetbiztonsági kockázat tényét, hogy ezzel összefüggésben semmilyen szakértői elemzésre nem támaszkodott. Végülis egy közelebbről meg nem nevezett nemzetbiztonsági kockázatra hivatkozás a bíróság számára elegendőnek bizonyult az arányossági vizsgálat mellőzésére, a korlátozás szükségességének az igazolásában felolvadtak az arányossági szempontok.

Az alapjog-korlátozás mértékének igazolhatóságát így viszont érdemben nem végezték el. Ebből fakad a döntés alapvető legitimációs problémája, ezért lehet inkább önkényesnek, mint megalapozottnak értékelni. Azóta tudjuk, hogy a jogalkotó legitimnek ítélt indokai sem voltak őszinték. ${ }^{6}$ A piacot nem nyilvános, meghívásos pályázatok útján újrafelosztották. A játék szenvedélybetegei tovább gazdagíthatják az arra méltónak talált vállalkozókat.

IV. Sok elemében hasonló folyamatokat lehet beazonosítani a szövetkezeti hitelintézetekről szóló törvénnyel kapcsolatban. Érdemes megnézni, hogy ebben az ügyben ${ }^{7}$ miként alkalmazta a bíróság az arányossági vizsgálatot.

Az alkotmányos kérdés az volt, hogy a törvény súlyosan megsértette-e a hitelintézetek tulajdonjoghoz való jogát vagy sem. Az indítványozók álláspontja szerint az alapjogkorlátozásnak nem volt elfogadható indoka, a törvény preambulumában írtak szerinti „átmenetiség”-et semmi nem támasztotta alá, a törvény nem rendelkezett a ,jogfosztás” ellentételezéséről, továbbá az integrációból $1^{8}$ történő kilépést is gyakorlatilag lehetetlenné tette.

Az indítványozók kisajátításnak tartották a Takarékbankban végrehajtott tőkeemelést, ${ }^{9}$ mivel ennek eredményeképpen az állam tulajdonában álló szervezetek ${ }^{10}$ együttesen többségi

\footnotetext{
${ }^{6} \mathrm{http}: / /$ szuveren.hu/jog/huvelykujjszabaly

${ }^{7}$ http://public.mkab.hu/dev/dontesek.nsf/0/AA42F88F8E53EB84C1257BBF001BACF4?OpenDocument

${ }^{8} \mathrm{http}: / /$ kozjavak.hu/hu/tud-e-repulni-lelott-madar-avagy-takarekszovetkezetek-integracioja-hazankban

${ }^{9}$ Az ennek során kibocsátott összes törzsrészvényt az állami tulajdonban álló Magyar Posta Zrt. jegyezhette le névértéken.

${ }^{10}$ Az MFB és a Magyar Posta.
} 
tulajdonosi pozícióba kerültek. Sérelmezték, hogy bizonyos takarékbanki részvényesek a törvény alapján a továbbiakban már nem lehetnek részvényesek (illetve részvényesi jogaikat nem gyakorolhatják), és hogy emellett a jogszabály több olyan esetet is szabályoz, melynek bekövetkezése esetében a részvényesek takarékbanki részvényeiket el is veszít(het)ik.

Az indítványozók az alapjog-korlátozás legitim indokait is vitatták. Állításaik szerint a törvényhozói szándékot semmilyen tény nem támasztja alá, sőt, a szektor az elmúlt években folyamatos fejlődést produkált, a szövetkezeti hitelintézetek stabilak, tőkeellátottságuk a nyilvánosság számára is elérhető információk alapján megfelelö, müködésük nyereséges. Hangsúlyozták, hogy az egyes szövetkezeteknél kialakuló esetleges problémák nem veszélyeztetik a rendszer egészét, tehát nem állt fenn olyan vészhelyzet, amely ilyen szintü állami beavatkozást tett volna szükségessé.

Az Alkotmánybíróság nem találta megalapozottnak az indítványozók aggályait, és elfogadta a jogalkotó helyzetértékelését, amely szerint

„a szektor kiegyensúlyozott müködéséhez az önkéntes szerződéses integrációnál többre van szükség ahhoz, hogy az érintett hitelintézetek egységes elvek szerint, az eddigieknél szorosabb felügyelet alatt müködjenek, s a válsághelyzetek megelözése érdekében - illetve bekövetkezésükkor - gyors, azonnali beavatkozási lehetőség álljon fenn. Az integrált müködés egyik elemét jelenti a törvény által létrehozott intézményvédelmi szervezetben (az SZHISZ-ben) való kötelezö tagság."

\section{Az Alkotmánybíróság álláspontja szerint}

„az összehangolt müködés, a hitelintézeti vezető tisztségviselőkkel szemben támasztott szakmai elvárások meghatározása és a hosszú távú, egységes müködési stratégia kialakítása hozzájárul az ad hoc hitelezési gyakorlat - és az ennek következtében kialakuló válsághelyzetek - megakadályozásához. A tagok prudens és profitábilis müködésének biztosítása érdekében létrehozott intézményi struktúra és az előírások végrehajtása érdekében bevezetett mechanizmusok (utasítások, szankciók) pedig az integráció müködését szolgálják. Az átlátható, prudens müködés biztosítása és a betétbiztonság növelése (és ezzel összefüggésben az ügyfelek tulajdonhoz való jogának a védelme) olyan alkotmányos értékek, melyek az egyesülési jog és az ezzel összefüggő cselekvési szabadság mint alapjog korlátozását szükségessé és alkotmányossá teszik."

Ezzel összefüggésben a bíróság hangsúlyozta, hogy a tulajdonhoz való jog korlátozása kapcsán viszonylag szük körü a vizsgálódási lehetősége abban a tekintetben, hogy mennyire megalapozott a jogalkotó részéről a közérdekre való hivatkozás.

A korlátozás arányosságának vizsgálata során az Alkotmánybíróság fontos szempontnak értékelte, hogy bár az integráció szerveinek irányítási jogai meghatározó módon befolyásolják a szövetkezeti hitelintézetek müködési önállóságát, ezt kompenzálják az összehangolt müködésből eredő előnyök, ${ }^{11}$ illetve az a tény, hogy a szektor stabilitásának és biztonságának védelme érdekében az állam az MFB-n keresztül jelentős összeggel járul hozzá az intézményvédelmi feladatok ellátásához, növelve a szektor pénzügyi stabilitását. Jogi értelemben az állam nemcsak elvesz a rendszerből (az egyes hitelintézetek önállóságából), hanem hozzá is ad (materiális fedezetet, biztonságot). A fentiekre tekintettel a bíróság arra a

\footnotetext{
${ }^{11}$ Elsősorban az üzleti kockázatok csökkenése és a jövedelmezőség növelése.
} 
következtetésre jutott, hogy az alapjog-korlátozás szükségessége és arányossága megállapítható.

Ez az érvelés azonban korántsem meggyőző. Legfontosabb fogyatékossága - hasonlóan a pénznyerő automatás ügyhöz -, hogy a többségi döntés ebben az esetben sem folytatott le valódi arányossági vizsgálatot. A bíróságnak azt kellett volna ugyanis igazolnia, hogy a szövetkezeti hitelintézetek reformja és konszodilációja más módon nem, csak a müködési önállóság és a tulajdonosi jog teljes korlátázásával érhető el. Erre azonban nem tett kísérletet, hiszen nyilvánvaló, hogy létezik egy másik út, ahogy arra Bragyova András is rámutatott a különvéleményében: „a takarékszövetkezetek már hosszabb ideje létező önkéntes integrációjának erősítése vagy módosítása".

A Lenkovics-féle indoklás úgy állítja be az arányossági tesztet mintha az valami tisztességes piaci alku lenne, ahol a törvényalkotó a céljai érdekében kedvére adja-veszi a szabadságkorlátozó hátrányokat és az anyagi előnyöket. Csakhogy a többségi indoklás által elvégzett mérlegelésnek se a tisztességes piaci alkuhoz nincs köze, de ami még súlyosabb, az arányossági teszthez sem. Hiszen ez utóbbi arról szól, hogy a törvényes cél érdekében csak a lehető legkevésbé alapjogkorlátozó szabályozási mód az elfogadható és választható, és a mérlegelés során nem az előnyöket és a hátrányokat próbálja kiegyensúlyozni, hanem a lehetséges szabályozási alternatívák egybevetése után ítéli meg, hogy van-e a törvényhozó által javasoltnál kevésbé korlátozóbb.

$\mathrm{Az}$ elemzett két esetet nemcsak a tulajdonjog korlátozása és az arányossági vizsgálat mellőzése kapcsolja össze, hanem a törvények elfogadásának a módja is. Mindkét döntés alapjául szolgáló törvényt az ún. kivételes sürgősségi eljárás keretében fogadták el, ami már önmagában komoly legitimációs problémákat vet fel, hiszen ezekből a törvényjavaslatokból a benyújtásuk után két-három napon belül törvény lett, úgyhogy az ellenzéknek csupán néhány órája maradt a javaslatok megismerésére és a módosító indítványok benyújtására. Kérdés, hogy az ilyen módon meghozott törvények esetében mennyire elfogadható az a bevett alkotmánybírósági gyakorlat, amely nem vizsgálja érdemben, hogy a törvényhozó hatalom által megnevezett közérdek a tulajdonjog korlátozásnak legitim indoka lehet vagy sem. Én arra hajlok, hogy ilyen törvényhozási eljárások esetén a törvényhozói indokokat eleve gyanúsnak kellene tekinteni.

Ha ezt a kérdést most nyitva is hagyjuk, az eddigiek alapján az világosan belátható, hogy a törvényhozó gyanús, tisztességtelennek tünő szabályozási indokai az arányossági teszt megfelelő alkalmazásával is kiszürhetőek lehettek volna. A mérlegelés megfelelö szempontjait az Emberi Jogok Európai Bírósága a Vékony kontra Magyarország ${ }^{12}$ ügyben világosan megfogalmazta.

A trafik ügyekben nemcsak az alkotmányos tulajdonvédelem terjedelmét tekintve van jelentős véleménykülönbség a magyar és a strasbourgi bíróság között, hanem az arányossági vizsgálat alkalmazásában is. Az Alkotmánybíróság a trafik-ügyben ${ }^{13}$ is beérte annyival az alapjogkorlátozás alkotmányosságának vizsgálata során, hogy elfogadta legitimnek a korlátozás céljait, és a célok elérése érdekében szükségesnek ítélte a korlátozást, de a korlátozás arányosságát itt sem vizsgálta. Azt, hogy a fenti esetekben milyen tesztet is kellett volna alkalmaznia az Alkotmánybíróságnak, a strasbourgi bíróság mutatta meg a már említett Vékony ügyben.

\footnotetext{
${ }^{12} \mathrm{http} / / /$ hudoc.echr.coe.int/eng\#\{"itemid":["001-149201"]\}

${ }^{13} \mathrm{http}: / /$ public.mkab.hu/dev/dontesek.nsf/0/A3FED588AED2CD7FC1257BBF001BAD97?OpenDocument
} 
Ezen teszt alapján a tulajdonjogot korlátozó intézkedéseknek „,megfelelő egyensúly”- $t$ kell találnia a közérdek, valamint az egyén alapvető jogai védelmének követelményei között. Nem állapítható meg a megfelelő egyensúly, amennyiben az érintett személy egyéni és túlzott terhet kénytelen viselni. A törvényhozás indokoltságát föszabály szerint el kell fogadni, kivéve ha az nyilvánvalóan indokolatlan volt, vagy az érintett személyre „túlzott terhet” rótt.

Ezen teszt alapján a konkrét esetben a strasbourgi bírák öt érvet hoztak fel amellett, hogy a trafikszabályozás sértette a kérelmező tulajdonjoghoz való jogát: (1) a pályázat értékelése során a korábbi engedély meglétét figyelmen kívül hagyták; (2) az új rendszerben nem vették fontolóra annak lehetőségét, hogy a korábbi engedély birtokosai folytathassák dohánytermékkiskereskedelmi tevékenységüket a megváltozott feltételek mellett; (3) a koncessziós rendszer lehetővé tette egy pályázó részére öt koncesszió megítélését, ami objektíve csökkentette az engedélyesek esélyeit, így különösen azokét, akik megélhetése számos éven keresztül a dohánytermékek árusításának lehetőségétől függött; (4) a koncessziók odaítélésére vonatkozó átlátható szabályok hiánya; (5) a korábbi engedély birtokosainak semmiféle előjogot nem adtak, például úgy, hogy a pályázat első körét rájuk korlátozták volna.

A magyar Alkotmánybíróságnak a „megfelelő egyensúly” megtalálásához a fent elemzett az ügyekben szükséglett volna némi szakmai tisztességre, civil kurázsira és az alapvető jogok védelme iránti minimális elhivatottságra. E három erény az igazolás kultúrájának is az alapja. Ha már a bírák is nélkülözik ezeket az erényeket, akkor a közjó eszménye is elveszik, nemcsak a demokratikus jogállam. 